\title{
In vitro Antioxidant Potential and Cytotoxicity Study of Asparagus aethiopicus L. Extracts on HT-29 Human Colon Cancer Cell Line
}

\author{
Suhas Suresh Awati ${ }^{1,2, \star}$, Ritu M Gilhotra1, Santosh K Singh', Vinit Raj', Kiran A Wadkar ${ }^{3}$ \\ ${ }^{1}$ School of Pharmacy, Suresh Gyanvihar University, Jaipur, Rajasthan, INDIA. \\ ${ }^{2}$ Dr. Shivajirao Kadam College of Pharmacy, Kasabe Digraj, Sangli, Maharashtra, INDIA. \\ ${ }^{3}$ Department of Pharmacognosy, Appasaheb Birnale College of Pharmacy, Sangli, Maharashtra, INDIA.
}

\begin{abstract}
Objectives: To decide the phytochemical constituents, antioxidant and anticancer potential of Asparagus aethiopicus L. extracts on HT-29 human colon malignant growth cell line. Methods: The roots of plant were exposed to Hot Soxhlet continuous extraction with expanding polarity of solvents viz., pet ether, chloroform, ethanol and aqueous maceration. Qualitative phytochemical screening was completed by utilizing distinctive phytochemical tests. The antioxidant potential was tried utilizing 2, 2-diphenyl-1picrylhydrazyl, ferric ion reducing power assay and phosphomolybdenum assay. In vitro anticancer action tried on HT-29 human colon malignant growth cell line and it was assessed by (3-(4, 5-dimethyl thiazole-2yl)- 2, 5-diphenyl tetrazolium bromide) MTT test. Results and Discussion: Preliminary qualitative phytochemical screening affirmed the presence of phytoconstituents like alkaloids, flavonoids, glycosides, saponins, sterols, tannins and reducing sugar. Antioxidant potential was demonstrated most noteworthy in ethanol extracts dependent on the test performed. The ethanol extracts were seen as an antioxidant and specifically cytotoxic to HT-29 human colon malignant growth cell line. Conclusion: The outcomes show that Asparagus aethiopicus L. having a potential of antioxidant activity and anticancer action on HT-29 human colon cancer cell line. In any case, further examinations are expected to presume that the particular constituent liable for its antioxidant action and cancer prevention agent.
\end{abstract}

Key words: Phytochemical, Antioxidant, Anticancer, Colon cancer, Asparagus aethiopicus.

\section{INTRODUCTION}

Cancer is a disease described by uncontrolled engendering of cells that have changed from the typical cells of the body. The malignant growth cells can attack the neighbouring and distant tissues via the circulation. In advanced stages, a malignant growth patient may die because of either ill-advised finding or treatment disappointment. Malignancy is one of the push zones for which powerful medications at reasonable costs are not accessible until now presumably because of an absence of understanding the disease pathophysiology. For such a ghastly infection hostile to malignancy drugs have been created from an assortment of sources extending from normal items (plants and organisms) to synthetic particles. The broadly utilized medications that are malignant growth chemotherapeutic specialists experience the ill effects of the downside of high danger, for example, bone marrow concealment, alopecia, queasiness and spewing and are not inside the compass of a typical man. ${ }^{1}$

Medicines acquired from plants have assumed a central job in the social insurance of ahead of schedule and late societies. Ayurveda, the Indian arrangement of
Submission Date: 21-03-2020; Revision Date: 29-05-2020; Accepted Date: 13-08-2020

DOI: 10.5530/ijper.54.3s.156 Correspondence:

Mr. Suhas Suresh Awati ${ }^{1}$ School of Pharmacy, Suresh Gyanvihar University, Jaipur, Rajasthan, INDIA.

${ }^{2}$ Dr. Shivajirao Kadam College of Pharmacy, Kasabe Digraj, Sangli-416301, Maharashtra, INDIA.

Phone: +919552581008

E-mail: awatiss@gmail.com

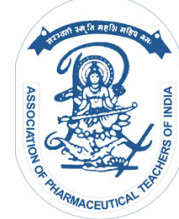

www.ijper.org 
medication for the most part utilizes plant based medications or formulations to treat different sicknesses including malignancy. About $60 \%$ of medications allowed for cancer treatment are of natural source. Vincristine, Etoposide, Irinotecan, Taxanes and Camptothecines are instances of plant-derived anti-cancer compounds. ${ }^{2}$

A few malignancies inquire about investigations accompanied using traditional medicinal plants in solidarity to find new helpful specialists that do not have the dangerous reactions connected with current chemotherapeutic agents and the medications under clinical trials, phytomedicines have improved strongly in the previous two decades. ${ }^{3}$

Current treatment of malignant growth has significantly more side effects to defeat from that; natural remedies are helpful, adequate and demanding by the disease patients because of its less or no toxic effect. Henceforth here is a significant need to create substitute restorative techniques against this deadly illness. There is consistently the expectation that the pursuit among the traditional therapeutic plants may furnish strong and safe prescriptions with few or no poisonous impacts.

Reactive oxygen species are thought to assume a significant job in numerous human maladies. Radical scavenging power is essential because of the lethal job of free radicals in biological systems. Numerous secondary metabolites like phenols, polyphenols and flavonoids fill in as wellsprings of antioxidants and perform scavenging activity. ${ }^{4}$

In spite of assuming a key job in cell forms, reactive oxygen species promptly join and oxidize biomolecules, for example, sugars, proteins and lipids and in this manner making them inactive with sub-sequent harm to cells, tissues and organs prompting beginning of numerous maladies including malignancy. In this manner, by diminishing free radicals and oxidative pressure, antioxidants assume a job in improving DNA harm, decreasing the rate of abnormal cell division and lessening mutagenesis. Hence, numerous antioxidantrich plants possess cancer prevention activity. 5,6

Asparagus aethiopicus L. (Sprengeri plant/Asparagus greenery) has a place with the family Asparagaceae; Modern taxonomists have put the genus Asparagus in family Asparagaceae of request Asparagales rather than in Liliaceae. It is a helpful traditional medicinal plant, saw as developed all through the tropical and subtropical pieces of India. The dried roots of plants are generally utilized as a drug. ${ }^{7-11}$ The plants from Asparagaceae family offers various medical advantages because of phytochemically a number of classes of phytoconstituents were isolated from plants of genus
Asparagus basically essential oils, flavonoids, saponin glycosides, tannins and sterols. The major bioactive constituents of asparagus are a gathering of steroidal saponins. This plant likewise contains vitamins A, B1, B2, C, E and Mg, P, Ca, Fe and folic acid. Other essential synthetic constituents of Asparagus are essential oils, asparagine, arginine, tyrosine, flavonoids (kaempferol, quercetin and rutin), gum, Shatavarin I-IV, asparagamine and tannin. From a pharmacological perspective, these varieties have antioxidant, cancer prevention, antidiabetic, anti-inflammatory, antimicrobial and immunostimulant exercises among others, affirming data got from ethno pharmacological studies. ${ }^{12-18}$ In any case, this plant has not been investigated for anticancer action on colon malignant growth and antioxidant properties of this plant. Subsequently, we have made an endeavor to utilize this natural plant to check the viability against colon malignant growth cell lines. The present investigation was intended to assess primer phytochemical assessment, in vitro antioxidant study and in vitro anticancer movement against HT-29 colon malignancy cell lines.

\section{MATERIALS AND METHODS Chemicals}

All solvents were analytical grade. Pet Ether, Chloroform, ethanol, Ascorbic acid, ferric chloride, aluminium chloride, potassium acetate, DPPH reagent, sodium carbonate, were obtained from Loba Chemie Pvt. Ltd. Mumbai. Shimadzu 1800 UV-Vis Spectrophotometer was utilized in all spectrophotometric estimations.

\section{Cell culture}

The human colon cancer cell line (HT-29) was obtained from National Centre for Cell Sciences (NCCS), Pune, India. The cells were kept up at $37^{\circ} \mathrm{C}$ in a humidified atmosphere $(90 \%)$ containing $5 \% \mathrm{CO}_{2}$ and afterword, cultured in (Dulbecco's Modified Eagle Medium) with low glucose, Thermo fisher scientific (Cat No-11965092) with $10 \%$ (v/v) FBS, 100 units/mL penicillin and $100 \mu \mathrm{g} / \mathrm{ml}$ streptomycin.

\section{Strategy for collection of plant}

The Asparagus aethiopicus L. chosen for the investigation was collected from the Kolhapur district of Maharashtra. The plant was authenticated by Dr. S. R. Yadav, HOD and Taxonomist Department of Botany, Shivaji University Kolhapur and Herbarium deposited having Voucher specimen no. SSA-02 in the Department of Botany, Shivaji University, Kolhapur, Maharashtra, India. 


\section{Phytochemical evaluation}

The root portion of Asparagus aethiopicus L. were collected, washed with water, shade dried and powdered. The powdered material was exposed to successive solvent extraction using Soxhlet apparatus with a selected order of polarity i.e. pet ether, chloroform, ethanol and water maceration. The extraction with solvent was continued until solvent from thimble of soxhlet apparatus get colourless. After extraction of every solvent, the powdered plant material was dried at room temperature and proceeds with next solvent extraction. The resulted successive extracts are concentrated on Rota evaporator and labelled as Pet ether Extract [PEAA], chloroform Extract [CEAA], Ethanol Extract [EEAA], Aqueous Extract [AEAA]. Then all extracts exposed to qualitative phytochemical investigation for the identification of phytoconstituents.

\section{Tests for carbohydrates}

The carbohydrates were tried by using Benedict's test, Fehling's test and Molisch test.

\section{Test for proteins}

Various extracts were dissolved in a few $\mathrm{ml}$ of water and treated with Million's reagent.

\section{Tests for Fats and Oils}

Fats and oils were tested with Translucent Spot test, Acrolein test,

\section{Tests for sterols}

The sterols were tested by using the LibermannBurchard test and the Salkowski test.

\section{Tests for glycosides}

Keller Kiliani Test, Borntrager's test were utilized for the analysis of glycosides.

\section{Test for saponins}

Foam test was performed for the presence of saponins.

\section{Test for Flavonoids}

The flavonoids were tested by the Shinoda test and Ferric chloride test.

\section{Tests for alkaloids}

The alkaloids have been tested by using the Dragendroff 's test and Wagner's test.

\section{Tests for tannins}

Test for tannins, ferric chloride test and lead acetate test were performed. ${ }^{19-21}$

\section{Pharmacological Evaluation \\ In vitro antioxidant activity}

The in-vitro antioxidant activity of different extracts of Asparagus aethiopicus L. studied by utilizing Ferric reducing antioxidant power (FRAP) assay, Phosphomolybdenum assay and 2, 2-Diphenyl-1picrylhydrazyl (DPPH) radical scavenging ability assay.

\section{Ferric ion reducing antioxidant power assay (FRAP)}

Ferric reducing antioxidant power (FRAP) assay is a broadly utilized technique that utilizes antioxidants as reductants in a redox-connected colorimetric response, Ferric iron $\left(\mathrm{Fe}^{3+}\right)$ is initially reduced by electron-giving antioxidants present inside the sample to its ferrous form $\left(\mathrm{Fe}^{2+}\right)$. The iron colorimetric test complex builds a dark blue color product upon reduction which can be measured at $700 \mathrm{~nm}$. Antioxidants are molecules that go about as reducing agents by giving electrons to free radicals to stabilize them and limit the harm brought about by free radicals to DNA, cells and organ systems. Antioxidant incorporates substances such as polyphenols; flavonoids; vitamins and enzymes like glutathione peroxidase and superoxide dismutase. ${ }^{22}$

FRAP assay were utilized to quantify the total antioxidant potential of the extracts. Antioxidant activity assays were performed by the technique portrayed by Benzie and Strain with slight drugs. All extract of Asparagus aethiopicus L. and Ascorbic acid in various concentrations ranging from $12.5 \mu \mathrm{g} / \mathrm{ml}$ to $200 \mu \mathrm{g} / \mathrm{ml}$ and were blended with $2.5 \mathrm{ml}$ of $0.2 \mathrm{mM}$ phosphate buffer ( $\mathrm{pH}$ 7.4) and $2.5 \mathrm{ml}$ of potassium ferricyanide [1\% weight/ volume $(\mathrm{W} / \mathrm{V})]$. The resulting mixture is incubated at $50^{\circ} \mathrm{C}$ for $20 \mathrm{~min}$, followed by the addition of $2.5 \mathrm{~mL}$ of trichloroacetic acid $(10 \% \mathrm{~W} / \mathrm{V})$ and centrifuged at 3000 $\mathrm{rpm}$ for $10 \mathrm{~min}$. At that point, $2.5 \mathrm{ml}$ of distilled water was included and later $0.5 \mathrm{ml}$ of ferrous chloride $(0.1 \%$ $\mathrm{W} / \mathrm{V}$ ). At long last, the absorbance was estimated at 700 $\mathrm{nm}$. Ascorbic acid was utilized as a positive reference standard. ${ }^{23}$

\section{Phosphomolybdenum assay (PM)}

The antioxidant assay depends on the reduction of Phosphate-Molybdenum (VI) to PhosphateMolybdenum (V). The incubation of extracts with the Molybdenum (VI) will communicate the presence of antioxidant constituents in the extract, which can be assessed by recording the absorbance at $695 \mathrm{~nm}$ (to distinguish the reduced green molybdenum complex). In this way, this assay is very helpful to conceive the antioxidant capability of crude extracts. 
The total antioxidant action was evaluated by Phosphomolybdenum (PM) assay utilizing the standard procedure of Prieto et al. All extracts of Asparagus aethiopicus L. and Ascorbic acid in different concentrations ranging from $12.5 \mu \mathrm{g} / \mathrm{ml}$ to $200 \mu \mathrm{g} / \mathrm{ml}$ were added to each test tube individually containing 3 $\mathrm{ml}$ of distilled water and $1 \mathrm{ml}$ of molybdate reagent. These tubes were kept incubated at $95^{\circ} \mathrm{C}$ for an hour and a half. After incubation, they are kept at room temperature for 20-30 $\mathrm{min}$ and the absorbance was estimated at $695 \mathrm{~nm}$. The positive reference standard was utilized in this assay was Ascorbic acid. ${ }^{23,24}$

\section{2, 2-Diphenyl-1-picrylhydrazyl (DPPH) radical scavenging ability assay}

The anti-oxidant capability of any compound can be resolved based on its scavenging activity of the stable 2,2-diphenyl-1-picrylhydrazyl (DPPH) free radical. DPPH is a steady free radical containing an odd electron in its structure and generally used for the detection of the radical scavenging activity in chemical analysis. ${ }^{25}$

The lambda max of a stable DPPH radical in methanol was at $517 \mathrm{~nm}$. The decline in absorbance of DPPH radical is brought about by antioxidants, in view of the reaction between antioxidant particles and radical progresses, which brings about the scavenging of the radical by hydrogen donation. ${ }^{26}$

Free radical scavenging effect of plant extract was resolved utilizing the 2-diphenyl-1picrylhydrazyl (DPPH) free radical. Briefly; the concentrations of extracts ranging from $12.5 \mu \mathrm{g} / \mathrm{ml}$ to $400 \mu \mathrm{g} / \mathrm{ml}$ were set up in ethanol. DPPH solution $(0.004 \%)$ was prepared in ethanol and $1 \mathrm{ml}$ of this solution was blended in with a similar volume of extracts and standard ascorbic acid solution separately. The mixture was incubated for half an hour in the dark at room temperature and the absorbance was measured at $517 \mathrm{~nm}$. The level of DPPH purple decolourization to DPPH yellow showed the scavenging effectiveness of the extract. Lower absorbance of the reaction mixture showed higher free radical-scavenging activity. The scavenging activity against DPPH was determined utilizing the equation: DPPH scavenging activity $(\%)=\mathrm{AC}-\mathrm{AT} / \mathrm{AC} \times 100$

AC: Absorbance of Control, AT: Absorbance of sample The results were analyzed in triplicate. The $\mathrm{IC}_{50}$ value is the concentration of the sample required to inhibit $50 \%$ of the DPPH free radical. ${ }^{23,27,28}$

\section{In-vitro anticancer activity}

The viability assay most as often as possible utilized all through the world is the MT'T assay. This colorimetric assay utilizes a reduction of a yellow tetrazolium salt (3-(4,5-dimethylthiazol-2-yl)-2,5-diphenyltetrazolium bromide, or MT'T) to measure cellular metabolic activity as a proxy for cell viability. Viable cells contain NAD(P) $\mathrm{H}$ - dependent oxidoreductase enzymes which reduce the MTT reagent to formazan, an insoluble crystalline product with a deep purple shading. Formazan crystals are then dissolved utilizing a solubilizing solution and absorbance is estimated at 500-600 nm utilizing a platereader. The darker the solution it indicates that more the quantity of viable and metabolically active cells. ${ }^{23,29-31}$

The in-vitro cytotoxicity study of various extracts of Asparagus aethiopicus L. was carried out by utilizing HT-29 human colon malignant growth cell lines.

The cells were seeded at a density of around $5 \times 10^{3}$ cells / well in a 96-well flat-bottom microplate and kept at $37^{\circ} \mathrm{C}$ in $95 \%$ humidity and $5 \% \mathrm{CO}_{2}$ overnight. Distinctive concentration $(800,400,200,100,50,25 \mu \mathrm{g} / \mathrm{ml})$ of samples were treated. The cells were incubated for extra $48 \mathrm{hr}$. The cells in well were washed twice with phosphate buffer solution and $20 \mu \mathrm{l}$ of the MTT (3-(4,5-dimethylthiazol-2yl)-2,5-diphenyl tetrazolium bromide), staining solution $(5 \mathrm{mg} / \mathrm{ml}$ in phosphate buffer solution) was added to each well and plate was incubated at $37^{\circ} \mathrm{C}$. After $4 \mathrm{hr}, 100 \mu \mathrm{l}$ of Dimethyl sulfoxide (DMSO) was added to each well to dissolve the formazan crystals and the absorbance at $570 \mathrm{~nm}$ was measured with UV- Spectrophotometer using DMSO as the blank. Measurements were performed and the concentration required for a $50 \%$ inhibition $\left(\mathrm{IC}_{50}\right)$ was determined. The $\%$ cell viability was determined utilizing the following formula:

$\%$ cell viability $=A_{570}$ of treated cells $/ A_{570}$ of control cells $\times 100$

$\mathrm{A}_{570}:$ Mean absorbance at $570 \mathrm{~nm}^{23,32,33}$

\section{Statistical analysis}

All the determinations of the experimental work were carried out in triplicates and the acquired information were classified and analyzed by using Microsoft Office Excel 2013. The results are expressed as mean values and standard Error Mean (SEM).

\section{RESULTS}

\section{Qualitative Phytochemical evaluation}

The existences of numerous secondary metabolites such as sterols, flavonoids, saponins, glycosides were recognized in ethanol and aqueous extracts. These significant metabolites were identified dependent on 
shading changes, the formation of precipitation or formation of persistent forms qualitatively. On the other hand, a minor amount of carbohydrate, alkaloids and tannins were recognized. Traces of fats and oils were found in Pet ether extract. (Table 1)

\section{In vitro antioxidant activity}

Antioxidant capacities were shown highest in ethanol extracts based on the FRAP assay, PM assay and DPPH radical scavenging ability assay.

\section{Ferric ion reducing antioxidant power assay}

In the present investigation, extracts of Asparagus aethiopicus L. were exposed to FRAP assay alongside standard ascorbic acid. In the results obtained, Ethanol extract showed higher action than other extracts which was comparable to standard Ascorbic acid [AS]. (Figure 1)

\section{Phosphomolybdenum assay}

The Pet Ether (PEAA), Chloroform (CEAA), Ethanol (EEAA) and Aqueous (AEAA) extracts of Asparagus aethiopicus L. were exposed to PM assay along with standard ascorbic acid. In the results obtained, Ethanol extract showed higher activity than other extracts which was comparable to standard Ascorbic acid. (Figure 2)

\section{2, 2-Diphenyl-1-picrylhydrazyl radical scavenging ability assay}

In the present study, Pet Ether (PEAA), Chloroform (CEAA), Ethanol (EEAA) and Aqueous (AEAA) extracts of Asparagus aethiopicus L. were subjected to DPPH free radical scavenging assay. The antioxidant potential of the extract was compared with ascorbic acid (AS) as the standard antioxidant. Ethanol extract showed higher activity than other extracts which was comparable to standard Ascorbic acid. (Figure 3) $\mathrm{IC}_{50}$ values of DPPH scavenging activity of extracts

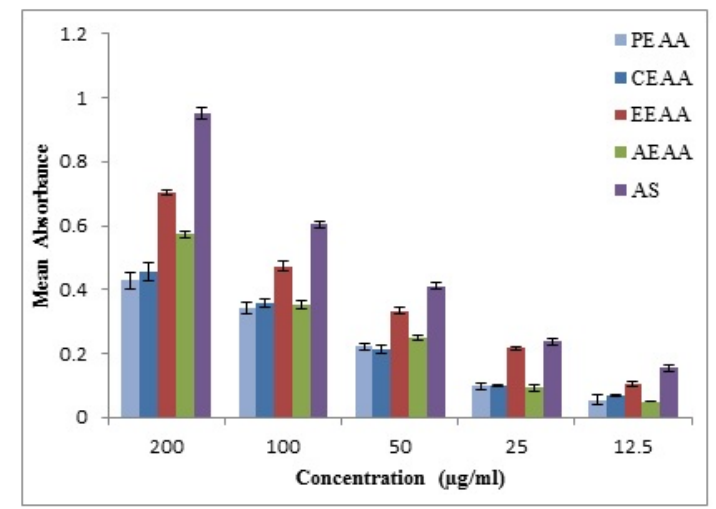

Figure 1: Mean absorbance at $700 \mathrm{~nm}$ of Asparagus aethiopicus L. extracts for FRAP assay. Data expressed as Mean \pm Standard error of the mean. of Asparagus aethiopicus L. for antioxidant activity are represented in (Table 2, Figure 4).

\section{In vitro anticancer activity}

The result of MTT assays revealed that the ethanol extract was found to be selectively cytotoxic to HT-29 human colon cancer cell line as compared to other extracts compared with mostly used Paclitaxel as cytotoxic and normal control (NC). (Table 3, Figure 5). $\mathrm{IC}_{50}$ values of extracts of Asparagus aethiopicus L. against HT-29 Colon cancer cell lines are represented in (Figure 6).

\section{DISCUSSION}

In recent years, the use of herbal medicines in cancer treatment has received increasing attention due to their varied Phyto-metabolic contents with multiple biological activities. ${ }^{34}$ The plant collected from the Western Ghats was recognized by their taxonomical characters as Asparagus aethiopicus L. and analyzed for the presence of phytochemicals with four solvent extracts. Preliminary Qualitative phytochemical analysis revealed the presence of secondary metabolites in the selected extracts of the plant (Table 1). These secondary metabolites are reported to have many biological and therapeutic properties. ${ }^{35}$ Among the various phytochemicals, sterols and flavonoids have picked up the regard for various zones of utilizations, for example, pharmaceutical, health, food and cosmetic ventures. These composites are basic in the plant space as piece of our everyday eating routine and are appealing as attractive natural antioxidants. ${ }^{36,37}$

Reactive oxygen species (ROS) are thought to assume a significant job in numerous human illnesses. Free Radical scavenging activities are exceptionally vital because of the poisonous job of free radicals in biological systems.

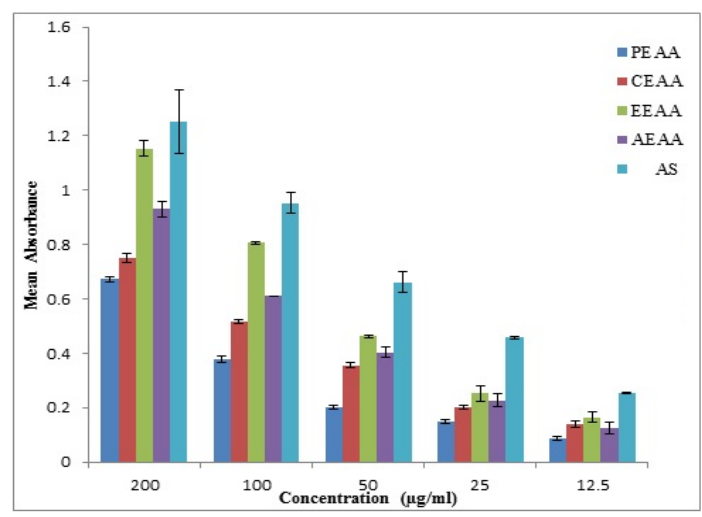

Figure 2: Mean absorbance at $695 \mathrm{~nm}$ of Asparagus aethiopicus L. extracts for PM antioxidant Assay. Data expressed as Mean \pm Standard error of the mean. 
Numerous secondary metabolites like flavonoids fill in as origins of antioxidants and do scavenging activity. ${ }^{38}$ ROS unreservedly consolidates and oxidizes biomolecules, for example, proteins, sugars and lipids in this manner making them lethargic with consequent harm to cells, tissues and organs prompting disease progression. ${ }^{39,40}$

In the present work, FRAP, PM and DPPH strategies were utilized to assess the entire antioxidant capacity of pet ether, chloroform, ethanol and aqueous extracts.

The Ferric ion reducing capability of the extract may help as a significant presentation of its antioxidant activity. The presence of antioxidants, which have been shown to be an impart antioxidant action by breaking the free radical chain by donating a hydrogen molecule. ${ }^{41}$ The presence of antioxidants in the extract would bring about the reduction of ferricyanide $\mathrm{Fe}^{3+}$ to ferrocyanide $\mathrm{Fe}^{2+}$ by giving an electron which was estimated spectrophotometrically at $700 \mathrm{~nm}$. In this assay, the yellow shade of the test solution changes to various shades of green and blue, depending on the reducing power of plant extract. The reducing

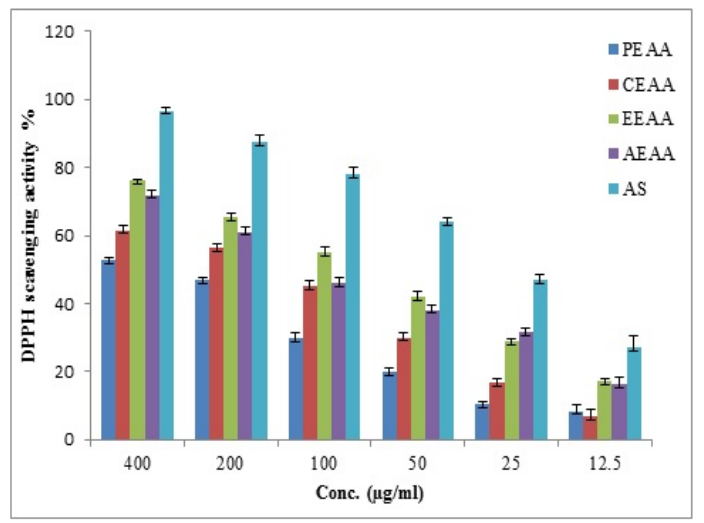

Figure 3: Percentage DPPH scavenging activity of Asparagus aethiopicus L. extracts for antioxidant activity. Data expressed as Mean \pm Standard error of the mean.

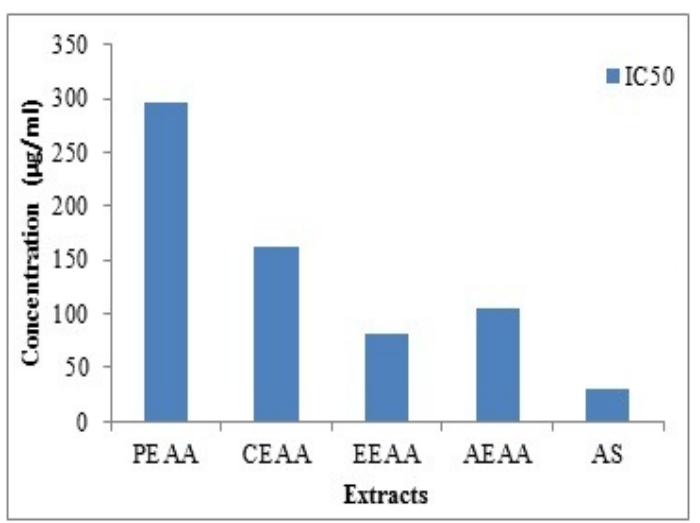

Figure 4: IC $C_{50}$ values of Asparagus aethiopicus L. extracts for DPPH radical scavenging antioxidant activity. power decreased with the decrease in the extract concentrations. This might be filled in as a critical marker of its antioxidant potential. The ethanol extract indicated more absorbance at $700 \mathrm{~nm}$ than other extracts (0.705 \pm 0.007$)$; subsequently this investigation assumed that ethanol extract of Asparagus aethiopicus L. may have a high measure of antioxidant property than other extracts which was comparable to that of the synthetic antioxidant standard used Ascorbic acid (Figure 1).

By utilizing phosphomolybdenum technique, the absolute antioxidant activity of the sample was investigated. It is a colorimetric quantitative technique that estimates the reduction of Phosphate-Mo (VI) to Phosphate-Mo (V) by the sample and resulting development of a pale blue green shaded Phosphate-Mo (V) complex. ${ }^{23}$ It helps to watch the reduction rate among antioxidant and molybdenum ligand. In the present investigation, ethanol extract displayed higher

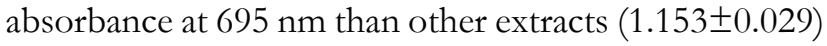
(Figure 2). Henceforth this examination perceived that ethanol extract of Asparagus aethiopicus L. may have a high measure of antioxidant property than other extracts

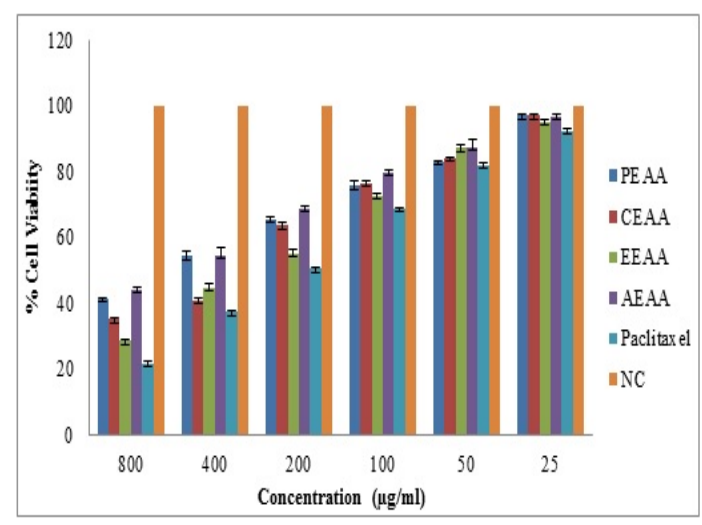

Figure 5: Percentage cell viability of Asparagus aethiopicus L. extracts for cytotoxicity on HT-29 colon cancer cell line. Data expressed as Mean \pm Standard error of the mean.

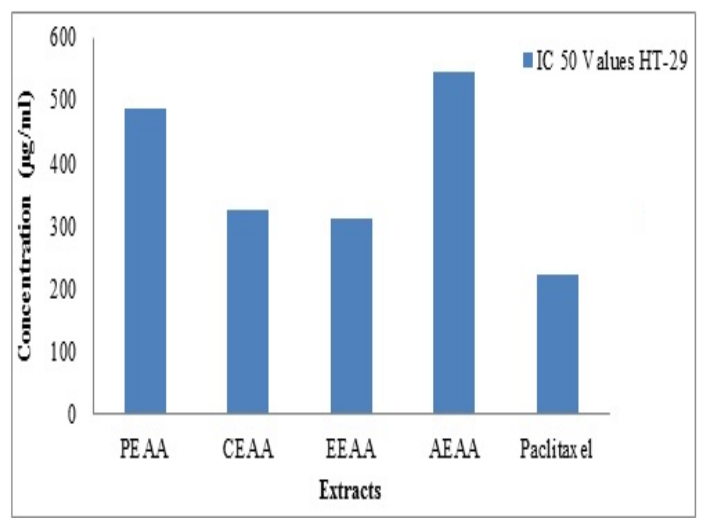

Figure 6: IC $\mathrm{I}_{50}$ values of Asparagus aethiopicus L. extracts for cytotoxicity on HT-29 colon cancer cell line. 


\section{Table 1: Qualitative Phytochemical Evaluation of Asparagus aethiopicus L.} extracts.

\begin{tabular}{|c|c|c|c|c|}
\hline Compounds & PEAA & CEAA & EEAA & AEAA \\
\hline Carbohydrates & - & - & + & + \\
\hline Proteins & - & - & - & + \\
\hline Fats and Oil & + & - & ++ & + \\
\hline Sterols & - & - & + & ++ \\
\hline Glycosides & - & - & +++ \\
\hline Saponins & - & + & + & ++ \\
\hline Flavonoids & - & + & + & + \\
\hline Alkaloids & - & - & + & + \\
\hline
\end{tabular}

+++: Strongly present, ++: Moderately present, +: Present in traces, -: Absent

Table 2: $\mathbf{I C}_{50}$ values of extracts of Asparagus aethiopicus L. for DPPH antioxidant activity.

\begin{tabular}{|c|c|}
\hline Compound & IC $_{50}(\boldsymbol{\mu} \mathbf{g} / \mathbf{m l})$ \\
\hline PEAA & 296.7 \\
\hline CEAA & 162.7 \\
\hline EEAA & 82.26 \\
\hline AEAA & 105.3 \\
\hline AS & 29.64 \\
\hline
\end{tabular}

which was practically comparable to that of synthetic antioxidant standard used Ascorbic acid.

DPPH is steady nitrogen focused free radical which is ordinarily used to decide free radical scavenging activities of antioxidants present in plant extracts or synthetic compound. ${ }^{42-44}$ The reduction capacity of DPPH radical is dictated by the decline in absorbance at $517 \mathrm{~nm}$ prompted by antioxidants. Greater absorbance

\begin{tabular}{|c|c|c|c|c|c|}
\hline $\begin{array}{c}\text { Conc. } \mu \mathrm{g} / \\
\mathrm{ml}\end{array}$ & PEAA & CEAA & EEAA & AEAA & Paclitaxel \\
\hline 800 & $41.44 \pm 0.25$ & $35.24 \pm 0.58$ & $28.65 \pm 0.33$ & $44.21 \pm 0.57$ & $21.87 \pm 0.68$ \\
\hline 400 & $54.41 \pm 1.51$ & $41.03 \pm 0.54$ & $44.68 \pm 1.36$ & $54.76 \pm 2.31$ & $37.39 \pm 0.43$ \\
\hline 200 & $65.59 \pm 0.62$ & $63.68 \pm 1.10$ & $55.24 \pm 1.13$ & $68.91 \pm 0.76$ & $50.53 \pm 0.50$ \\
\hline 100 & $75.74 \pm 1.42$ & $76.62 \pm 0.82$ & $72.79 \pm 0.69$ & $79.85 \pm 0.99$ & $68.83 \pm 0.51$ \\
\hline 50 & $83.09 \pm 0.30$ & $84.27 \pm 0.02$ & $87.35 \pm 1.07$ & $87.65 \pm 2.32$ & $82.01 \pm 0.84$ \\
\hline 25 & $97.18 \pm 0.70$ & $97.21 \pm 0.33$ & $95.24 \pm 0.58$ & $97.06 \pm 0.59$ & $92.6 \pm 0.48$ \\
\hline NC & \multicolumn{5}{|c|}{100} \\
\hline
\end{tabular}

Data expressed as Mean \pm Standard error of the mean.

of the reaction mixture specified lesser free radical scavenging activity. In the present examination, ethanol extract displayed higher free radical scavenging activity than other extracts $(76.33 \pm 1.09 \%$ ) (Figure 3). Thus this examination accepted that ethanol extract of Asparagus aethiopicus L. may have a high measure of antioxidant property than other extracts which was practically comparable to that of the standard synthetic antioxidant agent Ascorbic acid. The outcome indicated that ethanol extract significantly scavenges the free radical and was the most potent extract with an $\mathrm{IC}_{50}$ value of $82.26 \mu \mathrm{g} /$ $\mathrm{ml}$ (Table 2, Figure 4).
The evaluation of the cytotoxicity of plant extracts is important for innocuous treatment. It empowers the identification of the inborn toxicity quality of the plant. ${ }^{45,46}$ The MTT assay is utilized in screening the crude extracts to assess the toxicity. It could likewise give a sign of conceivable cytotoxic properties of the tested plant extracts. MTT assay depends on the reduction of MTT by mitochondrial dehydrogenase by purple formazan product. It is often utilized as an in vitro model framework to measurement of cytotoxic impacts of plant extracts against malignant growth cell lines. ${ }^{47,48}$ In vitro cytotoxicity test using HT-29 colon malignant cell lines was performed to screen potentially 
toxic compounds that affect basic cellular functions and morphology. The four extracts (Pet ether, Chloroform, Ethanol and Aqueous) of Asparagus aethiopicus L. appeared in vitro development hindrance consequences for the malignant growth cell lines (HT-29), while there was no impact on the development of normal cells. Such specific impacts were focus just as, incubation period subordinate, regarding concentration $(25,50,100$, $200,400,800 \mu \mathrm{g} / \mathrm{ml}$ ) of each extract were assessed in triplicates by sequential dilutions. Among these six concentrations, $800 \mu \mathrm{g} / \mathrm{ml}$ of ethanol extract was the best in creating percentage growth inhibition (Cell viability: $28.65 \pm 0.33 \%$ ) trailed by chloroform extract (Cell viability: $35.24 \pm 0.58 \%$ ) when compared with other extracts. However, the standard paclitaxel drug showed significant inhibition (Cell viability: 21.87 \pm 0.68 $\%$ ) on the malignant growth cell lines (Table 3, Figure 5). The outcome indicated that ethanol extract is having potential of anticancer activity with an $\mathrm{IC}_{50}$ value of $313.2 \mu \mathrm{g} / \mathrm{ml}$ (Figure 6).

\section{CONCLUSION}

It was seen that the plant Asparagus aethiopicus L. contains a wide assortment of secondary metabolites that hold potential to be a source of antioxidants and anticancer capability dependent on the analyses performed, which gives a logical proof to direct further examinations and research the lead compounds present in the plant and assess its anticancer potential on other cancer cell lines and on in vivo animal models and set forward an endeavour to carry out trials on human beings.

\section{ACKNOWLEDGEMENT}

We would like to thank Prof. D. D. Chougule, Principal, Dr. Shivajirao Kadam College of Pharmacy, Kasabe Digraj, Sangli, Maharashtra, and Mr. Vijay Kumbhar, Maratha Mandal's N.G.H. Institute of Dental Sciences \& Research Centre, Belgaum, Karnataka, India for provided necessary research facilities to carry out the research work.

\section{CONFLICT OF INTEREST}

The authors declare no conflict of interest.

\section{ABBREVIATIONS}

DPPH: 2, 2-Diphenyl-1-picrylhydrazyl; FRAP: Ferric reducing antioxidant power; PM: Phosphomolybdenum assay; MTT: (3-(4,5-dimethylthiazol-2-yl)-2,5diphenyltetrazolium bromide; PEAA: Pet ether Extract of Asparagus aethiopicus L.; CEAA: Chloroform Extract of Asparagus aethiopicus L.; EEAA: Ethanol Extract of Asparagus aethiopicus L.; AEAA: Aqueous Extract of Asparagus aethiopicus L.; AS: Ascorbic acid; NC: Normal control.

\section{REFERENCES}

1. Gupta SK. Drug Screening Methods. Jaypee Brothers Medical Publishers, New Delhi. 2004;419.

2. Grever MCB. Cancer drug discovery and development, cancer: Principles and practice of oncology, Lippincott-Raven, Philadelphia, PA. 2001;328-39.

3. Rao KVK, Stanley AS, Nair HK, Aalinkeel R, Mahajan S, Chawda MPN. Plant derived products as a source of cellular growth inhibitory pytochemicals on PC-3M, DU- 145 and LNCaP prostate cancer cell lines. Current Science. 2004;87:1585-8.

4. Diplock AT. Will the good fairies please prove to us that vitamin E lessens human degenerative disease?. Free Rad Res. 1997;27(5):11-32.

5. Siddique NA, Mujeeb M, Najmi AK, Akram M. Evaluation of antioxidant activity, quantitative estimation of phenols and flavonoids in different parts of Aeglemarmelos. African J Plant Sci. 2010;4(1):1-5.

6. Koksal E, Bursal E, Dikici E, Tozoglu F, Gulcin I. Antioxidant activity of Melissa officinalis leaves. J Med Plant Res. 2011;5(2):217-22.

7. Asparagus aethiopicus, Flora of Australia Online. ABRS, (C) Commonwealth of Australia. 1994. Retrieved 2009-07-29.

8. University of Florida. UF/IFAS Center for Invasives Plants. (http://plants.ifas. ufl.edu/plantdirectory/ asparagus-aethiopicus/).Gainesville, Florida.

9. Parson WT, Cuthbertson EG. Noxious weeds of Australia. CSIRO Publishing. $2001 ; 692$.

10. Scott JK, Batchelor KL. Climate-based prediction of potential distributions of introduced Asparagus species in Australia. Plant Protection Quarterly. 2006;21(3):91-8.

11. Wolff MA. Winning the war of Weeds: The Essential Gardener's Guide to Weed Identification and Control. Kenthurst, NSW: Kangaroo Press. 1999;43.

12. Negi JS, Singh P, Joshi GP, Rawat MS, Bisht VK. Chemical constituents of Asparagus. Pharmacognosy Reviews. 2010;4(8):215-20.

13. Patricia $\mathrm{YH}$, et al. Structural revision of shatavarins I and IV, the major components from the roots of Asparagus racemosus. Tetrahedron Letters. 2006;47(39):6965-9.

14. Kar DK, Sen S. Sarsasapogenin in callus culture of Asparagus racemosus. Curr Sci. 1985;54(12):585.

15. Saxena VK, Chaurasia S. A new isoflavone from the roots of Asparagus racemosus. Fitoterapia. 2001;72(3):307-9.

16. Sekine T, Fukasawa N, Kashiwagi Y, Ruangrungsi N, Murakoshi I. Structure of asparagamine A: A novel polycyclic alkaloid from Asparagus racemosus. Chem Pharm Bull. 1994;42(6):1360-2.

17. Sekine T, Fukasawa N, Murakoshi I, Ruangrungsi N. A 9,10-dihydrophenanthrene from Asparagus racemosus. Phytochemistry. 1997;44(4):763-4

18. Hoang LS, et al. Phytochemical composition, in vitro antioxidant and anticancer activities of quercetin from methanol extract of Asparagus cochinchinensis (LOUR.) merr. tuber. Journal of Medicinal Plants Research. 2013;7(46):3360-6.

19. Khandelwal KR. Practical Pharmacognosy. Techniques and Experiments. $9^{\text {th }}$ ed. Nirali Prakashan, Pune. 2002;149-53.

20. Kokate CK. Practical Pharmacognosy. $4^{\text {th }}$ ed. Vallabh Prakashan, Delhi. 1994;107-35.

21. Pallavi Y, Nutan M. Estimation of Antioxidant Activity and Total Phenol, Flavonoid Content among Natural Populations of Caper (Capparismoonii, Wight) from Western Ghats Region. Indian Journal of Pharmaceutical Education and Research. 2016;50(3):495-501.

22. Benzie IF, Strain JJ. The ferric reducing ability of plasma (FRAP) as a measure of antioxidant power: The FRAP assay. Analytical Biochemistry. 1996;239(1):70-6. 
23. Shridhar C. Ghagane SI, et al. In vitro antioxidant and anticancer activity of Leea indica leaf extracts on human prostate cancer cell lines. Integrative Medicine Research. 2017;6(1):79-87.

24. Prieto P, Manuel P, Miguel A. Spectrophotometric quantitation of antioxidant capacity through the formation of a phosphomolybdenum complex: Specific application to the determination of Vitamin E. Analytical Biochemistry. 1999;269(2):337-41.

25. Ravishankar MN, Srivastava N, Padh H, Rajani M. Evaluation of antioxidant properties of root bark of Hemidesmusindicus. Phytomedicine. 2002;9(2):153-60.

26. Nayan R, Bhalodia PB, Nariya RN, Acharya VJ. Pharmacological Study in vitro antioxidant activity of hydroalcoholic extract from the fruit pulp of Cassia fistula Linn. AYU. 2013;34(2):209-14.

27. Brand-Williams $W$, Marie-Elisabeth $C$. Use of a free radical method to evaluate antioxidant activity. LWT-Food Science and Technology. 1995;28(1):25-30.

28. Gezici S, Sekeroglu N, Kijjoa A. In vitro Anticancer Activity and Antioxidant Properties of Essential Oils from Populus alba L. and Rosmarinus officinalis L. from South Eastern Anatolia of Turkey. Indian J of Pharmaceutical Education and Research. 2017;51(3 Suppl):S498-503.

29. Igarashi $M$, Teruo $M$. The growth inhibitory effect of conjugated linoleic acid on a human hepatoma cell line, HepG2, is induced by a change in fatty acid metabolism, but not the facilitation of lipid peroxidation in the cells. Biochimicaet Biophysica Acta (BBA)-Molecular and Cell Biology of Lipids. 2001;1530(2):162-71.

30. Morshed M, et al. In vitro antimicrobial and cytotoxicity screening of Terminalia arjuna ethanol extract. International Journal of Biosciences. 2011;1(2):31-8.

31. Kılıç N, Derici MK, Büyük I, Aydın SS, Aras S, Cansaran-Duman D. Evaluation of in vitro Anticancer Activity of Vulpinic Acid and its Apoptotic Potential using Gene Expression and Protein Analysis. Indian J of Pharmaceutical Education and Research. 2018;52(4):626-34.

32. Bhat SS, Revankar VK, Kumbar V, Bhat K, Kawade VA. Synthesis, crysta structure and biological properties of a cis-dichloridobis (diimine) copper (II) complex. Acta Cryst. 2018;74(2):1-6.

33. Prabha MR, Nivethitha GK. Evaluation of in-vitro antioxidant and anticancer activity of Monochoria vaginalis leaves on Hep2 and HeLa cell lines. International Journal of Pharmaceutical Sciences and Research. 2019;10(7):3340-8.

34. Mann J. Natural products in cancer chemotherapy: Past, present and future. Nature Reviews Cancer. 2002;2(2):143-8.
35. Sankaranarayanan R, Sumathy $\mathrm{S}$. Antioxidant and antihemolytic activity of flavonoid extract from fruit peel of Punicagranatum. Asian Journal of Pharmaceutical and Clinical Research. 2013;6(2):211-4.

36. Sreeramulu D, Raghunath M. Antioxidant activity and phenolic content of roots, tubers and vegetables commonly consumed in India. Food Research International. 2010;43(4):1017-20.

37. Jaradat NA, Shawahna R, Hussein F, Al-Lahham S. Analysis of the antioxidant potential in aerial parts of Trigonella arabica and Trigonella berythea grown widely in Palestine: A comparative study. European Journal of Integrative Medicine. 2016;04:004.

38. Diplock AT. Will the 'good fairies' please prove to us that vitamin E lessens human degenerative disease?. Free Radical Research. 1997;27(5):511-32.

39. Siddique NA, et al. Evaluation of antioxidant activity, quantitative estimation of phenols and flavonoids in different parts of Aeglemarmelos. African Journal of Plant Science. 2010;4(1):001-5.

40. Koksal E, et al. Antioxidant activity of Melissa officinalis leaves. Journal of Medicinal Plants Research. 2011;5(2):217-22.

41. Oliveira I, et al. Total phenols, antioxidant potential and antimicrobial activity of walnut (Juglansregia L.) Green husks. Food and Chemical Toxicology. 2008;46(7):2326-31.

42. Kalaivani T, Lazar M. Free radical scavenging activity from leaves of Acacia nilotica (L.) Wild. Ex Delile, an Indian medicinal tree. Food and Chemical Toxicology. 2010;48(1):298-305.

43. El-Maati MFA, et al. Phenolic extracts of clove (Syzygiumaromaticum) with novel antioxidant and antibacterial activities. European Journal of Integrative Medicine. 2016;1-27.

44. Prabha SB, Mohini R, Ramesh KRA. Evaluation of in vitro Antioxidant, Antibacterial and Anticancer activities of leaf extracts of Cleome rutidosperma. Research J Pharm and Tech. 2017;10(8):2492-6.

45. Padmaja R, et al. Brine shrimp lethality bioassay of selected Indian medicinal plants. Fitoterapia. 2002;73(6):508-10.

46. Rahman MA, et al. Evaluation of cytotoxic potential and apoptotic effect of a methanolic extract of Bauhinia racemosa L. against a human cancer cell line, He La. European Journal of Integrative Medicine. 2016;8(4):513-8. http:// dx.doi.org/10.1016/j.eujim.2016.02.004.

47. Morshed $\mathrm{M}$, et al. In vitro antimicrobial and cytotoxicity screening of Terminaliaarjuna ethanol extract. International Journal of Biosciences. 2011;1(2):31-8.

48. Swarnalatha Y. Isolation of Flavonoids and their Anticancer Activity from Sphaeranthus amaranthoides in A549 Cell Line. Research J Pharm and Tech. 2015;8(4):462-7.

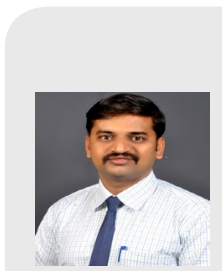

\section{About Authors}

Mr. Suhas S. Awati has completed B. Pharm from ABCP, Sangli, Maharashtra, M. Pharm (Pharmaceutical Chemistry) from KLES's College of Pharmacy, Belgaum, Karnataka and pursuing PhD from Suresh Gyanvihar University, Jaipur, Rajasthan. Presently he is working as an Assistant Professor at Department of Pharmaceutical Chemistry, Dr. Shivajirao Kadam College of Pharmacy, Kasabe Digraj Dist. Sangli, Maharashtra. He is having total 11 years of teaching experience. He has 14 research papers on his credit published in various peer reviewed national and international journals also he has presented research papers in national conferences and attended different national level workshops. He is having three books on his credit. He is a Life member of various professional associations like MSPC, APTI etc.

\section{SUMMAY}

- Asparagus aethiopicus L. contains a wide assortment of secondary metabolites like flavonoids, sterols, glycosides, alkaloids etc.

- These secondary metabolites hold potential to be a source of antioxidants and anticancer capability dependent on the analyses performed. 


\section{PICTORIAL ABSTRACT}

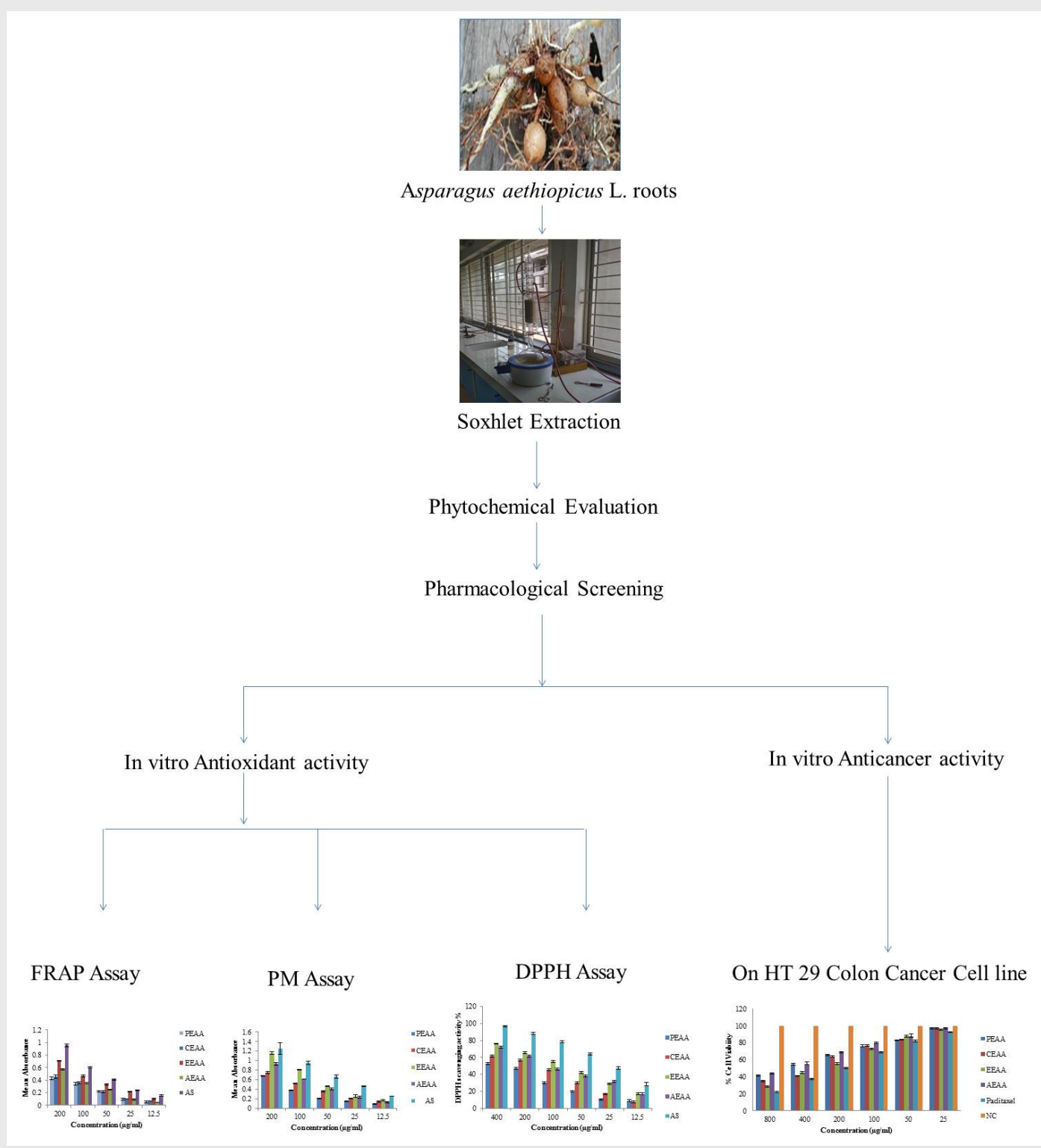

Cite this article: Awati SS, Gilhotra RM, Singh SK, Raj V, Wadkar KA. In vitro Antioxidant Potential and Cytotoxicity Study of Asparagus aethiopicus L. Extracts on HT-29 Human Colon Cancer Cell Line. Indian J of Pharmaceutical Education and Research. 2020;54(3s):s570-s579. 